\title{
Cannabis, the Endocannabinoid System and Immunity-The Journey from the Bedside to the Bench and Back
}

\author{
Osnat Almogi-Hazan *(i) and Reuven Or \\ Laboratory of Immunotherapy and Bone Marrow Transplantation, Hadassah Medical Center, The Faculty of \\ Medicine, Hebrew University of Jerusalem, Jerusalem 91120, Israel; reuvenor@hadassah.org.il \\ * Correspondence: osnath@hadassah.org.il
}

Received: 21 May 2020; Accepted: 19 June 2020; Published: 23 June 2020

\begin{abstract}
The Cannabis plant contains numerous components, including cannabinoids and other active molecules. The phyto-cannabinoid activity is mediated by the endocannabinoid system. Cannabinoids affect the nervous system and play significant roles in the regulation of the immune system. While Cannabis is not yet registered as a drug, the potential of cannabinoid-based medicines for the treatment of various conditions has led many countries to authorize their clinical use. However, the data from basic and medical research dedicated to medical Cannabis is currently limited. A variety of pathological conditions involve dysregulation of the immune system. For example, in cancer, immune surveillance and cancer immuno-editing result in immune tolerance. On the other hand, in autoimmune diseases increased immune activity causes tissue damage. Immuno-modulating therapies can regulate the immune system and therefore the immune-regulatory properties of cannabinoids, suggest their use in the therapy of immune related disorders. In this contemporary review, we discuss the roles of the endocannabinoid system in immunity and explore the emerging data about the effects of cannabinoids on the immune response in different pathologies. In addition, we discuss the complexities of using cannabinoid-based treatments in each of these conditions.
\end{abstract}

Keywords: Cannabis; cannabinoid; immune; inflammation; infectious diseases; virus; bacteria; cancer; autoimmune; transplantation

\section{Introduction}

The medical use of Cannabis is several thousand years old. The first historical evidence of Cannabis use in traditional medicine is documented in the ancient Chinese Pharmacopoeia, written in the first century BCE [1]. In Chinese medicine, Cannabis was used to treat rheumatic pain, constipation, malaria, beriberi, and gynecological disorders. Evidence of Cannabis use in ancient traditional medicine was uncovered in Japan, India, Iran, and Egypt as well as in Arabic medicine [2]. The medical use of Cannabis spread to the west only around the first century CE. Across the ancient world, the Cannabis treatment was documented to relieve a wide range of ailments including otitis, diarrhea, asthma, arthritis, and as a topical treatment of swellings and bruises. In parallel, Cannabis was historically used also during religious services and for recreational purposes [2]. Its use continued worldwide until 1925, when an agreement was reached to regulate and control both the commerce and the use of opium, cocaine, and other drugs. In 1941, Cannabis was removed by the United States from the National Formulary and from Pharmacopeia [3].

Although it was considered a dangerous drug in many countries worldwide, during the second half of the 20th century, basic research led to the discovery of cannabinoids, cannabinoid receptors, and the endocannabinoid system [4]. In recent years, under increasing pressure from patients and 
their families and the emergent problem of opiate dependency, an increasing number of countries have introduced more permissive policies on the use of Cannabis-based medical treatments. However, the limited evidence-based data on the efficacy and side effects of different Cannabis-based treatments in various medical conditions, prevents many physicians from suggesting such treatments to their patients. The accumulation of data from recent studies and results from ongoing research, will hopefully allow physicians to reach a more thorough understanding of Cannabis-based treatments allowing the appropriate application of cannabinoids to the clinic.

\section{The Phyto-Cannabinoid Activity Is Mediated by the Endocannabinoid System and Other Physiological Signaling Systems}

Cannabis contains numerous molecules, including more than 60 chemical compounds classified as cannabinoids, and the different Cannabis chemotypes vary in their cannabinoid composition [5]. The two most extensively studied phyto-cannabinoids (natural plant cannabinoids) are D9 tetrahydrocannabinol (THC) and cannabidiol (CBD). Other active phytochemicals include Terpenes and Phenolic Compounds such as flavonoids.

The diverse and powerful effects of many phyto-cannabinoids on the human (and animal) physiology are the result of their binding with the endogenous cannabinoid receptors and are affected by the levels of their endogenous ligands. These receptors and ligands together with the enzymes and transporters which control their metabolism comprise the endocannabinoid system. This endogenous cannabinoid system is conserved throughout evolution from coelenterates to man [6].

The "classical" members of the endogenous system are the endocannabinoids $N$-arachidonoylethanolamine (anandamide, AEA) and 2-arachidonoylglycerol (2-AG), and the cannabinoid receptors: Cannabinoid receptor 1(CB1) and Cannabinoid receptor 2(CB2). AEA is synthesized from membrane phospholipid precursors mainly by the sequential action of $N$-acyltransferase (NAT) and Nacyl-phosphatidylethanolaminesspecific phospholipase D (NAPE-PLD). 2-AG is synthesized by two diacylglycerol lipases (DAGL $\alpha / \beta$ ). The endocannabinoids bio-activities are terminated by their fast catabolism, mainly through hydrolysis by a fatty acid amide hydrolase (FAAH), for AEA, and by a monoacylglycerol lipase (MAGL), for 2-AG. AEA has been demonstrated to have a high affinity for CB1 and a low CB2 affinity, while 2-AG has a moderate affinity for both receptors $[7,8]$. Recently, more molecules were defined as endocannabinoids including 2-arachidonoyl glyceryl ether (noladin ether, 2-AGE), $\mathrm{O}$-arachidonoylethanolamine (virodhamine), $\mathrm{N}$-arachidonoyldopamine (NADA), and oleic acid amide (oleamide, OA) [9].

The cannabinoid receptors $\mathrm{CB} 1$ and $\mathrm{CB} 2$ are members of the $\mathrm{G}$ protein-coupled receptor (GPCR) family. GPCR's share common structural motifs, including the characteristic seven $\alpha$-helical structured transmembrane domains, an extracellular N-terminus, and a changeable intracellular C-terminus [10]. CB1 and CB2 were discovered about 30 years ago [11-13], however, their crystal structure was only recently determined, allowing a better understanding of ligand selectivity and function [14,15]. CB1 is mainly expressed in the brain and is therefore the main mediator of the psychoactive effects of Cannabis, whereas CB2 has a greater expression in the immune system. CB2 expression in lymph nodes and spleen is higher than in peripheral blood cells and is different in various immune cell populations (B cells $>$ NK cells $>$ monocytes $>$ neutrophils $>$ CD8 T-cells $>$ CD4 T-cells) [16,17]. Both receptors couple to $\mathrm{G}_{\mathrm{i} / \mathrm{o}}$ proteins and modulate various intracellular signal transduction pathways, including inhibition of adenylyl cyclase activity, calcium channels and D-type potassium channels, increase in the phosphorylation of mitogen-activated protein kinases (MAPK), and activation of A-type potassium channels. However, CB1 unlike CB2, has been reported to activate other G proteins in certain circumstances $[18,19]$.

In addition to CB1 and CB2 receptors, endocannabinoids have also been reported to modulate several other receptors and channels including several transient receptor potential (TRP) channels, GPCRs such as GPR 55, GPR18, GPR119, $\gamma$-aminobutyric acid (GABA) A, glycine receptors, and the nuclear receptor peroxisome proliferator-activated receptor gamma (PPAR- $\gamma$ ) $[7,20]$. 
Endocannabinoids are implicated in numerous physiological and pathological processes. Dysregulation of the endocannabinoid system, owing to variation in the concentration of endocannabinoids or the expression and function of cannabinoid receptors and enzymes, has been associated with several conditions, such as acute stress, autism, Alzheimer's disease, Mastocytosis, and cancer [21-25]. The accumulated discoveries on the endocannabinoid system triggered the search for targeted cannabinoid-based therapeutics [26].

THC and some of the other phyto-cannabinoids mediate their biological effects primarily through the classical cannabinoid receptors: CB1 and CB2. In addition, THC can act as an agonist of the receptors/channels GPR55, GPR18, PPAR $\gamma$, transient TRPA1, TRPV2, TRPV3, and TRPV4, and as an antagonist of the receptors/channels TRPM8 and 5-HT3A. Moreover, THC can increase AEA and adenosine levels [8]. Interestingly enough, although CBD affects the immune function, it has a very weak affinity to CB2 or CB1, where it can act as a negative allosteric modulator [27]. Several reports have demonstrated that CBD act as an agonist of the receptors/channels TRPA1, TRPV1, TRPV2, TRPV3, PPAR $\gamma$, 5-HT1A, A2 and A1 adenosine, and as an antagonist of the receptors GPR55, GPR18, and 5-HT3A. CBD is also an inverse agonist of the receptors GPR3, GPR6, and GPR12 and elevates AEA levels $[20,28,29]$.

\section{The Roles of the Endocannabinoid System in Immunity}

It is now clear that many of the components of the endocannabinoid system function as key regulators of the immune system and the immune response. The endocannabinoid system plays an important role in migration of hematopoietic stem and progenitor cells. Kose et al. demonstrated that endocannabinoids can stimulate migration of human hematopoietic stem cells in a cannabinoid receptor dependent manner [30]. They also showed that in healthy individuals, the concentration of the endocannabinoid 2-AG in blood plasma is higher than in bone marrow plasma. Pereira et al. proved that $\mathrm{CB} 2$ has a role in the retention of immature B cells in the bone marrow [31] and Hoggatt et al. demonstrated a significant decrease in CXCR4 in bone marrow cells treated with the CB1/CB2 agonist CP55940 [32]. Our own recently published results demonstrate that CB2 is involved in the inhibition of lymphocyte recovery after bone marrow transplantation (BMT) [33].

The endocannabinoid system is also involved in the regulation of mature immune cell trafficking and effector cell functions (Figure 1). For example, Szabady et al. demonstrated how endocannabinoids play a key regulatory role in the function of intestinal neutrophils. They demonstrated that the transporter P-glycoprotein (P-gp) secretes endocannabinoids into the intestinal lumen that counteract the pro-inflammatory actions of the neutrophil chemoattractant eicosanoid hepoxilin A3. Moreover, the anti-inflammatory actions of P-gp-secreted endocannabinoids-are mediated by CB2 receptors on neutrophils [34]. Kapellos et al. recently published that the CB2 deficiency exacerbates acute neutrophils mobilization to sites of inflammation [35]. In the respiratory syncytial virus (RSV) infection in mice, the level of neutrophil infiltrating the pulmonary airways following an RSV infection was significantly enhanced by blocking CB2 with AM630 [36]. Other innate immune cells are also regulated by endocannabinoids. Both murine and human monocytes/macrophages and microglial cells, express the CB1 and CB2 receptors [16,37-41]. Research by Acharya et al. showed that the engagement of the cannabinoid receptors augments the number and immune suppressive function of the regulatory CX3CR1hi macrophages in the gut [42]. In addition, CB2 is involved in the inhibitory function of tumor associated macrophages [43]. Adhikary et al. demonstrated that signaling through CB2 suppresses dendritic cell (DC) migration by inhibiting the matrix metalloproteinase 9 expression [44]. On the other hand, Maestroni suggested that the endocannabinoid 2-AG may act as a chemotactic substance capable of recruiting DCs and/or their precursors during the innate immune response [45]. 


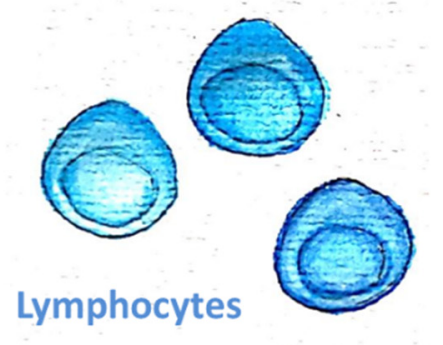

- $\quad$ CB1 and CB2 activity reduces IL-2 synthesis (32).

- $\mathrm{CB} 2$ is involved in the suppression of T cell activation $(33,47,49,50)$.

- GPR55 is involved in T-cell migration (52).

- $\mathrm{CB} 2$ has a role in the retention of immature $B$ cells in the bone marrow (31).

- AEA induces immunosuppression in B cells (53).

- Production of 2-AG by activated B cells and T cells modulates inflammation (54).

- CB2 ligation reduces vaccination induced immunity (55)

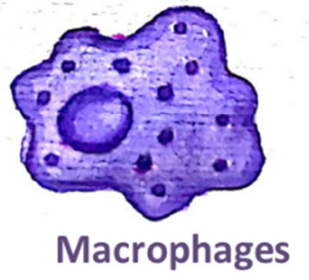

Endocannabinoid activity augments immune suppressive function of macrophages (42-43).

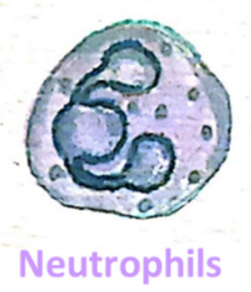

Endocannabinoid activity reduces neutrophil mobilization to sites of inflammation (34-36)

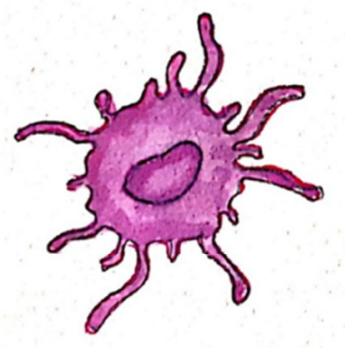

\section{Dendritic cells}

- CB2 activity reduces DC migration (44).

- 2-AG act as chemoattractant for DCs (45).

Figure 1. The endocannabinoid system is involved in the regulation of immune cell trafficking and effector cell functions. CB1/CB2: Cannabinoid receptor 1/2; AEA: $N$-arachidonoylethanolamine; 2-AG: 2-arachidonoylglycerol.

The endocannabinoid system is also involved in the regulation of adaptive immunity. Although T-cells express less CB2 than other immune cells, it has been demonstrated that T-cell's stimulation can upregulate the expression of CB2 receptors [46,47], and also induce CB1 expression [48]. In vitro assays revealed that cannabinoids inhibit T-cell activation via CB2 and other receptors, [33,47,49]. IL2 is a fundamental cytokine involved in T-cell activity and differentiation, secreted from activated T-cells, NK cells, and DCs. Both CB1 and CB2 receptor engagement reduce IL-2 synthesis [50]. In an in vivo model of experimental autoimmune encephalomyelitis, CB2-deficient T-cells in the central nervous system exhibited reduced levels of apoptosis, a higher rate of proliferation and increased production of inflammatory cytokines, resulting in severe clinical disease [51]. Sumida et al. recently demonstrated a role for another receptor, GPR55, in intraepithelial T-lymphocyte migration dynamics in the small intestine [52].

The endocannabinoid system's role in a mature B-cell function was demonstrated by Eisenstein et al. who showed that anandamide induces dose-related immunosuppression in both the primary and secondary in vitro plaque-forming cell assays of antibody formation [53]. Sido et al. used a delayed-type hypersensitivity in vivo model to demonstrate that the production of 2-AG by activated B-cells and T-cells modulates inflammation [54]. Importantly, Dotsay et al. recently demonstrated that CB2 ligation reduces vaccination-induced immunity. Transient administration of the CB2 antagonists during immunization heightened the intensity and breadth of antigen-specific antibody responses in young and aged mice [55].

Taken together, these examples indicate that the endocannabinoid system is a key regulator of the immune system (Figure 1), therefore any treatment which modulates its function will have immunologic effects. 


\section{The Effects of Cannabinoid-Based Treatments in Different Immune Related Diseases}

Moderate inflammation provides a beneficial protective effect against infections and long-term adaptive immunity toward specific pathogens. However, chronic or uncontrolled inflammation, resulting from unremitting immune system activation, often causes persistent tissue damage [56]. For example, patients with various autoimmune diseases, undergo treatment to gain control of their immune system and thereby reduce inflammation. On the other hand, in those with suppressed immunity, such as cancer patients we aim to boost the immune response against the tumor. Our research and many other studies have demonstrated immune-regulatory properties for Cannabis and cannabinoid-based treatments $[33,57,58]$. The effects of cannabinoid-based treatments in some immune related diseases (Figure 2) will be reviewed here.

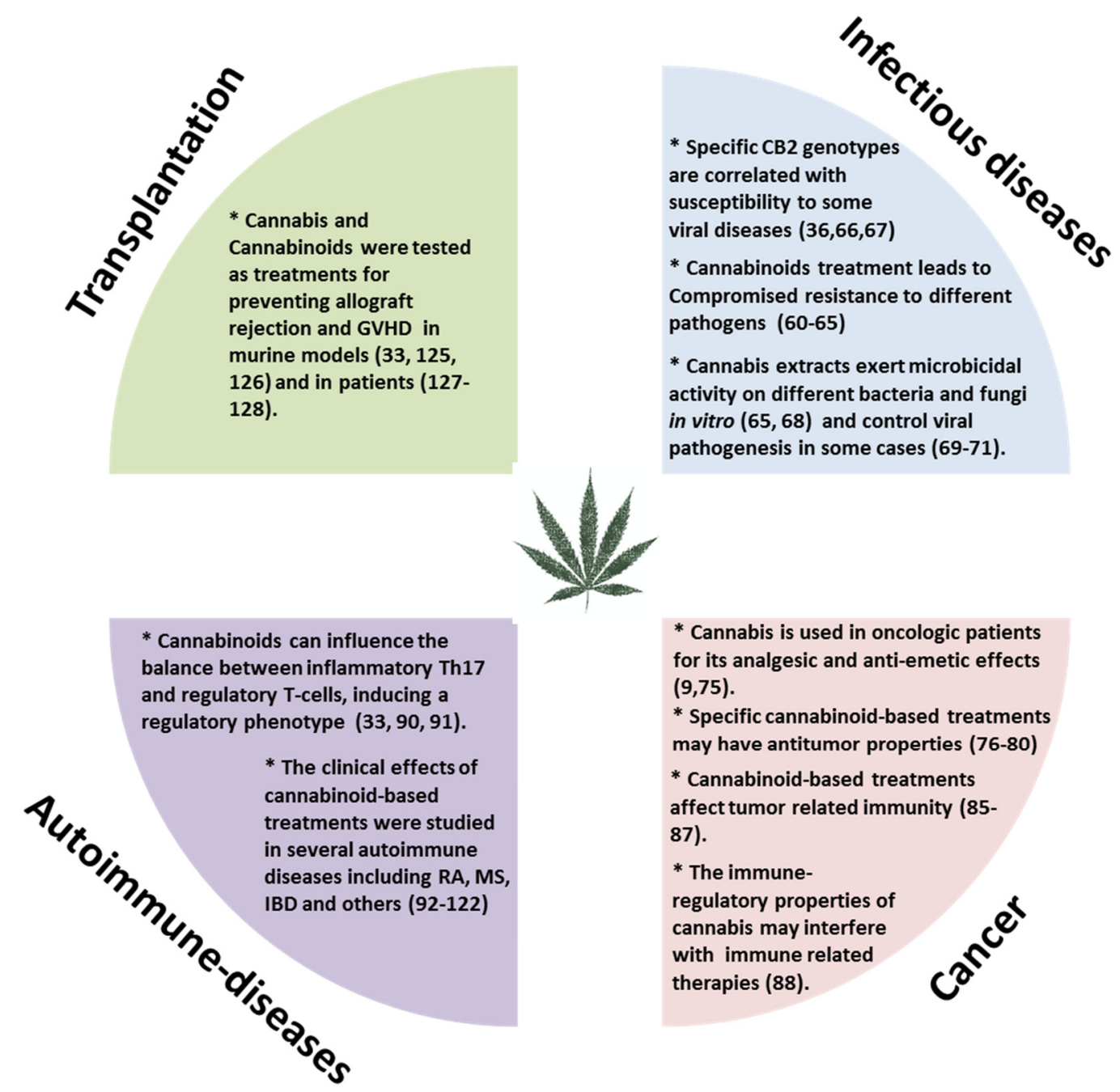

Figure 2. The effects of cannabinoid-based treatments in immune related diseases. GVHD: Graft versus host disease; RA: Rheumatoid arthritis; MS: Multiple sclerosis; IBD: Inflammatory bowel disease; CB2: Cannabinoid receptor 2 .

\subsection{Infectious Diseases}

The immune system has the important function of defending the host from foreign agents and pathogens. Researchers have explored the influence of cannabinoids on the immune system's reaction against pathogens for more than 40 years. In 1977, Bradley et al. showed that the combination of THC and lipopolysaccharide (LPS) is highly toxic in mice and the lethal capability of heat-killed bacteria is enhanced when THC is administered [59]. The same group also investigated the effects 
of THC and Cannabis extracts on host resistance to Listeria, monocytogenes, and herpes simplex virus [60]. Compromised resistance to different pathogens was demonstrated during the following years [61-64]. Later on, the roles of the endocannabinoid system in the induction of immunity by bacterial pathogens were established [65] and specific CB2 genotypes were found to correlate with susceptibility to some viral diseases $[36,66,67]$. On the other hand, in vitro studies demonstrated that cannabinoids exert microbicidal activity on different bacteria and fungi $[65,68]$ and could also control viral pathogenesis in some cases [69-71]. In a murine model for Malaria, oral administration of Cannabis increased the survival of infected mice [72]. In addition, Batugedara et al. observed increased levels of endocannabinoids in the lung and intestine of helminths infected mice and demonstrated that this elevation was associated with improved host immunity [73].

Taken together, the clinical effect of a cannabinoid-based treatment in infectious diseases is the consequence of both its anti-inflammatory effect and its influence on the specific pathogen.

Another subject for consideration is the role of the endocannabinoid system in vaccination and the effects of Cannabis and cannabinoid-based treatments on vaccination related immunity. Dotsey et al. investigated the effect of transient CB2 blockade on the immune response to vaccination in young and aged mice and demonstrated that such treatment heightens the intensity and breadth of antigen-specific immune responses [55]. However, a prospective study of humoral and cellular immune responses to hepatitis B vaccination in habitual marijuana smokers did not reveal a major impact on the development of systemic immunity [74].

\subsection{Cancer}

Currently, cannabinoid-based treatments are administered to oncologic patients as palliative medicines due to their analgesic and anti-emetic effects [9,75] (Table 1). Recent studies suggested that some cannabinoid-based treatments might also have antitumor properties [76,77]. However, most of these studies utilized in vitro methods, a few were done in immune-competent animal models [78-80], and the data from human patients is anecdotal. In addition, a large diversity was found in the expression of endocannabinoid related molecules in different kinds of tumors [81,82], and therefore cannabinoid-based treatments with dissimilar compositions may be effective only in specific cancer sub-types [77].

Table 1. Selected current clinical trials, synthetic, and botanical cannabinoid-based therapies in immune related diseases.

\begin{tabular}{|c|c|c|c|c|c|}
\hline Indication & Treatment & Bot/syn & Phase & $\begin{array}{c}\text { Status } \\
\text { (Updated on) }\end{array}$ & $\begin{array}{l}\text { ClinicalTrials.gov } \\
\text { Identifiers/ } \\
\text { EudraCT Number }\end{array}$ \\
\hline $\begin{array}{c}\text { Inflammation } \\
\text { (Observational study) }\end{array}$ & Cannabis & bot & n.a. & $\begin{array}{c}\text { Recruiting } \\
\text { (August 2018) }\end{array}$ & NCT03522103 \\
\hline $\begin{array}{c}\text { Cachexia; } \\
\text { Advanced Cancer }\end{array}$ & THC/CBD & syn & Phase 3 & $\begin{array}{c}\text { Not yet recruiting } \\
\text { (May 2020) }\end{array}$ & NCT04001010 \\
\hline $\begin{array}{l}\text { Glioblastoma; } \\
\text { Cancer }\end{array}$ & THC/CBD & n.a. & Phase 1-2 & $\begin{array}{l}\text { Not yet recruiting } \\
\text { (April 2020) }\end{array}$ & NCT03529448 \\
\hline $\begin{array}{l}\text { Chemotherapy } \\
\text { induced Nausea } \\
\text { and Vomiting; } \\
\text { Pancreatic Cancer }\end{array}$ & Dronabinol & syn & Phase 3 & $\begin{array}{l}\text { Recruiting } \\
\text { (April 2020) }\end{array}$ & $\begin{array}{c}\text { NCT03984214 } \\
\text { 2019-000616-28 }\end{array}$ \\
\hline $\begin{array}{c}\text { Chemotherapy } \\
\text { induced Peripheral } \\
\text { Neuropathy; } \\
\text { Cancer }\end{array}$ & Cannabinoids & n.a. & Phase 2 & $\begin{array}{c}\text { Recruiting } \\
\text { (September 2019) }\end{array}$ & NCT03782402 \\
\hline $\begin{array}{l}\text { Cancer cachexia; } \\
\text { Pancreatic cancer }\end{array}$ & Cannibinols & syn & n.a. & $\begin{array}{c}\text { Ongoing } \\
\text { (January 2018) }\end{array}$ & 2017-000530-54 \\
\hline
\end{tabular}


Table 1. Cont.

\begin{tabular}{|c|c|c|c|c|c|}
\hline Indication & Treatment & Bot/syn & Phase & $\begin{array}{c}\text { Status } \\
\text { (Updated on) }\end{array}$ & $\begin{array}{l}\text { ClinicalTrials.gov } \\
\text { Identifiers/ } \\
\text { EudraCT Number }\end{array}$ \\
\hline $\begin{array}{l}\text { Solid Tumor; } \\
\text { Cancer }\end{array}$ & Cannabis & bot & n.a. & $\begin{array}{l}\text { Recruiting } \\
\text { (March 2020) }\end{array}$ & NCT03617692 \\
\hline Rheumatoid arthritis & THC/CBD & bot & n.a. & $\begin{array}{c}\text { Temporarily } \\
\text { Halted } \\
\text { (October 2018) }\end{array}$ & 2017-004226-15 \\
\hline $\begin{array}{l}\text { Spasticity Due to } \\
\text { Multiple Sclerosis }\end{array}$ & BX-1 & bot & Phase 3 & $\begin{array}{c}\text { Recruiting } \\
\text { (January 2020) }\end{array}$ & NCT03756974 \\
\hline $\begin{array}{l}\text { Inflammatory } \\
\text { Bowel Diseases }\end{array}$ & Nabilone & syn & n.a. & $\begin{array}{l}\text { Not yet recruiting } \\
\text { (February 2020) }\end{array}$ & NCT03422861 \\
\hline Crohn's Disease & THC/CBD & n.a. & Phase 1-2 & $\begin{array}{l}\text { Completed } \\
\text { (March 2019) }\end{array}$ & NCT01826188 \\
\hline $\begin{array}{l}\text { Systemic Lupus } \\
\text { Erythematosus }\end{array}$ & JBT-101 & syn & Phase 2 & $\begin{array}{c}\text { Recruiting } \\
\text { (March 2020) }\end{array}$ & NCT03093402 \\
\hline Type 2 Diabetes & Cannabis & bot & n.a. & $\begin{array}{l}\text { Recruiting } \\
\text { (March 2020) }\end{array}$ & NCT04114903 \\
\hline
\end{tabular}

Sources: ClinicalTrials.gov, EU Clinical Trials Registery. Abbreviations: syn: Synthetic, bot: Botanical; n.a.: Not available.

The tumor microenvironment is a complex ecosystem, including blood vessels, immune cells, fibroblasts, extracellular matrix, cytokines, hormones and other factors. In addition to the tumor itself, different factors of the tumor microenvironment are involved in cancer progression. It is now clear that malignant development and progression is highly dependent on immune responses [83]. In recent years, immunotherapy has revolutionized the era of cancer treatment, restoring tumor-induced immune deficiency in the tumor microenvironment and modulating immune responses against cancers [84]. The understanding of cannabinoid-based treatments effects on the tumor microenvironment's immunity is essential to provide personalized therapeutical plans for varying oncologic patients and for the development of future combined therapies. Unfortunately, data from basic and medical research dedicated to this subject is currently limited. McKallip et al. reported that THC enhances breast cancer growth and metastasis by suppression of the antitumor immune response, in mice injected with 4T1 tumor cells [85]. In models of lung carcinoma and alveolar carcinoma, THC treated immune-competent mice demonstrated enhanced tumor growth but not in immune-incompetent mice, indicating an immune-related mechanism [86]. Whereas in a model of melanoma xenograft others reported inhibition of tumor growth by synthetic CB1 or CB2 agonists in both immune-competent mice and immune-incompetent mice [87]. In an ex vivo experiment, Zgair et al. showed that CBD and THC had similar anti-proliferative effects, both on PBMCs isolated from patients on chemotherapy regimens for non-seminomatous germ cell and on PBMCs from healthy volunteers [58].

Only one study has investigated the possible drug-drug effects of cannabinoids with immunotherapy. In retrospective, an observational study in patients treated with nivolumab, Taha et al. demonstrated that the use of Cannabis during immunotherapy treatment decreased the response rate, without affecting progression-free survival or overall survival and without relation to the Cannabis composition [88].

\subsection{Autoimmune Diseases}

Some of the most established data on the endocannabinoid system's immune related roles and the effects of phyto- and synthetic- cannabinoids on immunity, come from pre-clinical studies of autoimmune diseases $[20,89]$. Several groups have shown that cannabinoids can influence the balance between inflammatory Th17 and regulatory T-cells $[33,90,91]$, inducing a regulatory phenotype. The clinical effects of cannabinoid-based treatments were studied in several inflammatory, autoimmune related diseases. Rheumatoid arthritis (RA) is one of the most prevalent autoimmune diseases, 
statistics show it is among the main causes of disability worldwide, causing unbalanced pain and joint malformation and destruction. Malfait et al. showed that the CBD treatment effectively blocks the progression of arthritis in a murine collagen-induced arthritis model [92]. Similarly, Gui et al. demonstrated that the activation of cannabinoid receptor 2 attenuates synovitis and joint destruction in collagen-induced arthritis in mice [93]. Another interesting approach is elevating endocannabinoid levels by inhibition of their degrading enzymes. Lowin et al. and McDougll et al. demonstrated beneficial effects for treatments that include FAAH inhibitors in murine models for osteoarthritis (OA) and RA [94,95]. In patients with OA and RA increased FAAH activity was detected in the synovia and the endocannabinoids AEA and 2-AG were identified in the synovial fluid [96]. However, although several FAAH inhibitors were entered into clinical trials for different applications, none of them have reached approval for clinical use thus far, [97] and one of the phase I studies was terminated due to neurologic adverse effects in some of the participants [98]. The efficacy, tolerability, and safety of a Cannabis-based medicine (Sativex) to relieve pain caused by RA was assessed in one clinical trial [99]. In this randomized, double-blind, parallel group study with 58 patients over five weeks of treatment, a significant analgesic effect was observed and disease activity was significantly suppressed. A study that will test the efficacy and safety of using CBD and THC for the treatment of pain in patients with inflammatory arthritis is planned (Table 1).

Multiple sclerosis (MS) is a progressive, long-term autoimmune demyelinating disease of the central nervous system. Neuroprotection in experimental autoimmune encephalomyelitis by Cannabis-based cannabinoids was demonstrated in animal models [51,100-102]. Cannabinoid-based treatments were also examined clinically in MS patients. Sexton et al. detected a significant increase in the endocannabinoid AEA, in serum from individuals with MS compared to control subjects. The effect of Cannabis use on the tested immunological properties was similar in patients and in control subjects. For example, serum levels of IL-17 were significantly reduced in non-naive subjects, whether cases or controls [103]. Several randomized clinical trials examined the efficacy of cannabinoid treatment in MS. In a meta-analysis of clinical trials on the use of cannabinoids for spasticity due to MS, da Rovare et al. found an insignificant difference related to spasticity between cannabinoids and placebo $(p=0.18)$ [104]. Recently, Akgün et al. systematically reviewed publications on the THC:CBD spray use for refractory MS spasticity and found that the proportion of patients reaching the threshold of minimal clinical important (CI) difference, with at least a $20 \%$ reduction of the spasticity Numeric Rating Scale score after four weeks ranged from $41.9 \%$ to $82.9 \%$ [105]. A current study examines the efficacy of Cannabis in spasticity due to MS (Table 1).

Inflammatory bowel disease (IBD) is a general classification based on symptomology. It is comprised of well-known gastrointestinal inflammatory disorders such as Ulcerative colitis (UC), Crohn's (CD), etc. Cannabinoid receptors as well as endocannabinoids are upregulated in inflammation, and their presence and stimulation attenuates murine colitis, while cannabinoid receptor antagonism and cannabinoid receptor deficient models reverse these anti-inflammatory effects $[8,106]$. Both FAAH and MAGL inhibitors reduce disease scores in colitis mouse models $[107,108]$. In patients, some endocannabinoid molecules were differentially expressed in various bowel diseases. For example, AEA and oleoylethanolamide (OEA) were increased in the plasma of UC and CD patients while 2-AG was elevated in patients with CD, but not UC [109].

Several questionnaire-based studies have validated Cannabis use in $6.8-15.9 \%$ of adult patients with IBD. The most common reasons given were to alleviate abdominal pain, diarrhea, or anorexia [110]. In a small prospective placebo-controlled study, Naftali et al. demonstrated significant clinical, steroid-free benefits for 10 out of 11 patients with an active CD treated with THC rich Cannabis; although induction of remission was not achieved within the eight-week study [111]. Irving et al. performed a randomized, double-blind, placebo-controlled, parallel-group, study of cannabidiol-rich botanical extract in the symptomatic treatment of UC. In this study, the physician's global assessment of illness severity, subject global impression of change, and patient-reported quality-of-life were improved for patients taking a CBD-rich botanical extract $(p=0.069, p=0.003$, and $p=0.065$, respectively). However, patients were 
less tolerant of the CBD-rich botanical extract compared with the placebo [112]. Recently, Mbachi et al. evaluated several UC-related complications and clinical endpoints in a total of 298 Cannabis users with UC as compared to a propensity score matched group of nonusers with UC. Their results show that the prevalence of partial or total colectomy was lower in Cannabis users compared to nonusers $(p=0.01)$ and there was a trend toward a lower prevalence of bowel obstruction $(p=0.057)$. Cannabis users had a shorter duration of hospitalization $(p<0.007)$ compared to their nonuser counterparts [113]. Current studies examine combined THC and CBD drops for the treatment of Crohn's disease and the use of a synthetic cannabinoid, Nabilone, in IBD patients (Table 1). In addition to their anti-inflammatory effects, the beneficial consequences of the cannabinoids' treatment in IBD may be attributed by their influence on the permeability of the gastrointestinal tract. Couch et al. recently demonstrated that aspirin causes an increase in the absorption of lactulose and mannitol, which could be reversed by palmitoylethanolamide (PEA) or CBD treatment $(p<0.001)$ in a human, randomized, double-blind, controlled trial [114].

There is also evidence that suggests the involvement of cannabinoids in other autoimmune diseases. For example, Hegde et al. demonstrated attenuation of experimental autoimmune hepatitis by cannabinoids [115]. In a mouse model of myasthenia gravis, a cannabinoid receptor agonist reversed fatiguing failure of neuromuscular transmission [116]. Anti-inflammatory effects were also evident in a rodent model of autoimmune uveoretinitis treated with a CB2-selective agonist [117]. In a murine model for systemic lupus erythematosus (SLE), the CBD treatment was found to accelerate disease progression [118] and in patients, an involvement of the endocannabinoid system in the pathogenesis of this disease was described $[119,120]$. An ongoing study will examine the efficacy of JBT-101, a CB2 agonist, in SLE patients (Table 1). A decreased likelihood of diabetes for Cannabis users versus non-users was also suggested $[121,122]$ and currently the anti-inflammatory properties of Cannabis and their relevance to insulin sensitivity in Type 2 diabetes is being examined (Table 1).

\subsection{Transplantation}

Transplantation medicine is a rapidly evolving field and over the last years there has been substantial progress in organ exchange strategies. Allogeneic organ/BMT therapy is dependent on the success of suppressing recipient immune responses to the foreign organ (organ rejection) and/or the pathologic immunity of the transplant against the recipient's tissues (known as graft versus host disease-GVHD). Immunosuppressive drugs are the standard of care, although they are associated with numerous side effects, among the most significant are opportunistic infections and transplant-related malignancies.

Due to their anti-inflammatory properties, cannabinoids were suggested as potential treatments for preventing allograft rejection/GVHD [123,124]. The efficacy of cannabinoids, and particularly Cannabis extract, was demonstrated in murine models of GVHD [33,125] and skin allograft [126]. The efficacy of CBD as a prophylactic treatment for GVHD was also demonstrated in a phase II clinical trial [127]. Cuñetti et al. showed pain improvement in six out of seven kidney transplant patients receiving CBD, but they did not examine the effect on organ rejection [128]. Greenan et al. did not find any significant effect from the Cannabis recreational use on kidney allograft outcomes at one-year after renal transplantation. However, in these patients Cannabis use was defined by a positive urine toxicology screen and/or self-reported recent use, and the Cannabis chemotypes, time of administration, and doses vary [129].

\section{How to Choose the Best Treatment?}

Many cannabinoid-based treatments are currently available; they are either based on pure cannabinoids or on different chemotypes of the Cannabis plant. Although there is abundant information regarding the influence of Cannabis and cannabinoids on the immune system, the effect of pure cannabinoids such as THC and CBD and different Cannabis treatments was rarely compared. Several papers, including our own, demonstrated that Cannabis based treatments achieve better clinical results 
than pure cannabinoids (known as the entourage effect), in animal models $[33,130,131]$. It has been suggested that this is due to the combination of cannabinoids with other active molecules in the plant, for example terpenes and flavonoids [132].

In order to provide evidence-based data to better understand the medical potential in Cannabis treatments, several groups have compared different Cannabis chemotypes for the treatment of specific conditions. For example, Kamal et al. used a systems approach for finding Cannabis chemotypes with anxiolytic properties [133] and Johnson et al. compared the efficacy, safety, and tolerability of THC+CBD Cannabis extracts and the THC Cannabis extract in patients with intractable cancer-related pain [134]. In addition, Morgan et al. tested the individual and combined effects of pure THC and CBD on psychotomimetic symptoms and memory function [135]. However, none of these studies have tested the immunological consequences of these treatments. In our murine models, the effects of THC-high Cannabis extract and CBD-high Cannabis extract on inflammation were not significantly different [33].

The accumulating data about various molecules that can be found in Cannabis plants [5] together with advanced laboratory methods, allows for a better characterization of the Cannabis chemotypes used for therapy. Hopefully in the future clinicians will be able to prescribe the most efficient chemotype for a specific disease.

\section{Conclusions}

The essential regulatory role that the endocannabinoid system plays in immunity makes it a candidate for medical intervention in cases of immune related diseases. However, since the endocannabinoid system is widely expressed in the body and deeply involved in the function of the neurological system, body metabolism, and bone homeostasis [23], it is extremely important to consider all consequences of the treatment. On the other hand, the immune-modulatory effects of cannabinoid-based medicines may be detrimental in other instances. For example, medications that include cannabinoids such as THC and CBD may be used to treat nausea, chronic pain, sleeping disorders, or epilepsy. However, in some oncologic patients, administration of such medications may hold the risk of suppressing desired immunological reactions against pathogens and tumor cells. To these immunological concerns we should add the risks of Cannabis allergies [136-138] and cross-allergies, mostly due to its botanical origins [139]. In addition, it is essential to consider that cannabinoid-based medicines may reduce the efficacy of vaccination, mainly in children and elderly patients.

Author Contributions: Conceptualization, O.A.-H. and R.O.; writing-original draft preparation, O.A.-H.; writing-review and editing, O.A.-H. and R.O.; project administration, O.A.-H.; funding acquisition, R.O. All authors have read and agreed to the published version of the manuscript.

Funding: This research received no external funding.

Acknowledgments: The authors wish to thank Jeremy Lyons for his help in editing the manuscript and to Shakked Hazan for the illustrations.

Conflicts of Interest: The authors declare no conflict of interest.

\section{References}

1. Jiang, H.E.; Li, X.; Zhao, Y.X.; Ferguson, D.K.; Hueber, F.; Bera, S.; Wang, Y.F.; Zhao, L.C.; Liu, C.J.; Li, C.S. A new insight into Cannabis sativa (Cannabaceae) utilization from 2500-year-old Yanghai Tombs, Xinjiang, China. J. Ethnopharmacol. 2006, 108, 414-422. [CrossRef] [PubMed]

2. Pisanti, S.; Bifulco, M. Medical Cannabis: A plurimillennial history of an evergreen. J. Cell Physiol. 2019, 234, 8342-8351. [CrossRef] [PubMed]

3. Pisanti, S.; Bifulco, M. Modern History of Medical Cannabis: From Widespread Use to Prohibitionism and Back. Trends Pharm. Sci. 2017, 38, 195-198. [CrossRef] [PubMed]

4. Mechoulam, R.; Hanus, L.O.; Pertwee, R.; Howlett, A.C. Early phytocannabinoid chemistry to endocannabinoids and beyond. Nat. Rev. Neurosci. 2014, 15, 757-764. [CrossRef] 
5. Andre, C.M.; Hausman, J.F.; Guerriero, G. Cannabis sativa: The Plant of the Thousand and One Molecules. Front Plant Sci. 2016, 7, 19. [CrossRef] [PubMed]

6. Salzet, M.; Breton, C.; Bisogno, T.; Di Marzo, V. Comparative biology of the endocannabinoid system possible role in the immune response. Eur. J. Biochem. 2000, 267, 4917-4927. [CrossRef]

7. Maccarrone, M.; Bab, I.; Bíró, T.; Cabral, G.A.; Dey, S.K.; Di Marzo, V.; Konje, J.C.; Kunos, G.; Mechoulam, R.; Pacher, P.; et al. Endocannabinoid signaling at the periphery: 50 years after THC. Trends Pharmacol. Sci. 2015, 36, 277-296. [CrossRef]

8. Martínez, V.; Iriondo De-Hond, A.; Borrelli, F.; Capasso, R.; Del Castillo, M.D.; Abalo, R. Cannabidiol and Other Non-Psychoactive Cannabinoids for Prevention and Treatment of Gastrointestinal Disorders: Useful Nutraceuticals? Int. J. Mol. Sci. 2020, 21, 3067. [CrossRef]

9. Laezza, C.; Pagano, C.; Navarra, G.; Pastorino, O.; Proto, M.C.; Fiore, D.; Piscopo, C.; Gazzerro, P.; Bifulco, M. The Endocannabinoid System: A Target for Cancer Treatment. Int. J. Mol. Sci. 2020, 21, 747. [CrossRef] [PubMed]

10. Duc, N.M.; Kim, H.R.; Chung, K.Y. Structural mechanism of G protein activation by G protein-coupled receptor. Eur. J. Pharmacol. 2015, 763, 214-222. [CrossRef]

11. Devane, W.A.; Dysarz, F.A., 3rd; Johnson, M.R.; Melvin, L.S.; Howlett, A.C. Determination and characterization of a cannabinoid receptor in rat brain. Mol. Pharmacol. 1988, 34, 605-613. [PubMed]

12. Matsuda, L.A.; Lolait, S.J.; Brownstein, M.J.; Young, A.C.; Bonner, T.I. Structure of a cannabinoid receptor and functional expression of the cloned cDNA. Nature 1990, 346, 561-564. [CrossRef] [PubMed]

13. Munro, S.; Thomas, K.L.; Abu-Shaar, M. Molecular characterization of a peripheral receptor for cannabinoids. Nature 1993, 365, 61-65. [CrossRef] [PubMed]

14. Hua, T.; Vemuri, K.; Nikas, S.P.; Laprairie, R.B.; Wu, Y.; Qu, L.; Pu, M.; Korde, A.; Jiang, S.; Ho, J.H.; et al. Crystal structures of agonist-bound human cannabinoid receptor CB(1). Nature 2017, 547, 468-471. [CrossRef] [PubMed]

15. Li, X.; Hua, T.; Vemuri, K.; Ho, J.H.; Wu, Y.; Wu, L.; Popov, P.; Benchama, O.; Zvonok, N.; Locke, K.; et al. Crystal Structure of the Human Cannabinoid Receptor CB2. Cell 2019, 176, 459-467. [CrossRef]

16. Galiegue, S.; Mary, S.; Marchand, J.; Dussossoy, D.; Carriere, D.; Carayon, P.; Bouaboula, M.; Shire, D.; Le Fur, G.; Casellas, P. Expression of central and peripheral cannabinoid receptors in human immune tissues and leukocyte subpopulations. Eur. J. Biochem. 1995, 232, 54-61. [CrossRef]

17. Parolaro, D. Presence and functional regulation of cannabinoid receptors in immune cells. Life Sci. 1999, 65, 637-644. [CrossRef]

18. Demuth, D.G.; Molleman, A. Cannabinoid signalling. Life Sci. 2006, 78, 549-563. [CrossRef]

19. Zou, S.; Kumar, U. Cannabinoid Receptors and the Endocannabinoid System: Signaling and Function in the Central Nervous System. Int. J. Mol. Sci. 2018, 19, 833.

20. Olah, A.; Szekanecz, Z.; Biro, T. Targeting Cannabinoid Signaling in the Immune System: “High"-ly Exciting Questions, Possibilities, and Challenges. Front. Immunol. 2017, 8, 1487. [CrossRef]

21. Dlugos, A.; Childs, E.; Stuhr, K.L.; Hillard, C.J.; de Wit, H. Acute stress increases circulating anandamide and other N-acylethanolamines in healthy humans. Neuropsychopharmacology 2012, 37, 2416-2427. [CrossRef] [PubMed]

22. Karhson, D.S.; Krasinska, K.M.; Dallaire, J.A.; Libove, R.A.; Phillips, J.M.; Chien, A.S.; Garner, J.P.; Hardan, A.Y.; Parker, K.J. Plasma anandamide concentrations are lower in children with autism spectrum disorder. Mol. Autism. 2018, 9, 18. [CrossRef] [PubMed]

23. Hillard, C.J. Circulating Endocannabinoids: From Whence Do They Come and Where are They Going? Neuropsychopharmacology 2018, 43, 155-172. [CrossRef] [PubMed]

24. Aran, A.; Eylon, M.; Harel, M.; Polianski, L.; Nemirovski, A.; Tepper, S.; Schnapp, A.; Cassuto, H.; Wattad, N.; Tam, J. Lower circulating endocannabinoid levels in children with autism spectrum disorder. Mol. Autism. 2019, 10, 2. [CrossRef]

25. Solas, M.; Francis, P.T.; Franco, R.; Ramirez, M.J. CB2 receptor and amyloid pathology in frontal cortex of Alzheimer's disease patients. Neurobiol. Aging. 2013, 34, 805-808. [CrossRef] [PubMed]

26. Di Marzo, V. New approaches and challenges to targeting the endocannabinoid system. Nat. Rev. Drug Discov. 2018, 17, 623-639. [CrossRef]

27. McPartland, J.M.; Glass, M.; Pertwee, R.G. Meta-analysis of cannabinoid ligand binding affinity and receptor distribution: Interspecies differences. Br. J. Pharmacol. 2007, 152, 583-593. [CrossRef] 
28. Burstein, S. Cannabidiol (CBD) and its analogs: A review of their effects on inflammation. Bioorg. Med. Chem. 2015, 23, 1377-1385. [CrossRef]

29. Elmes, M.W.; Kaczocha, M.; Berger, W.T.; Leung, K.; Ralph, B.P.; Wang, L.; Sweeney, J.M.; Miyauchi, J.T.; Tsirka, S.E.; Ojima, I.; et al. Fatty acid-binding proteins (FABPs) are intracellular carriers for $\Delta$ 9-tetrahydrocannabinol (THC) and cannabidiol (CBD). J. Biol. Chem. 2015, 290, 8711-8721. [CrossRef]

30. Kose, S.; Aerts-Kaya, F.; Kopru, C.Z.; Nemutlu, E.; Kuskonmaz, B.; Karaosmanoglu, B.; Taskiran, E.Z.; Altun, B.; Uckan Cetinkaya, D.; Korkusuz, P. Human bone marrow mesenchymal stem cells secrete endocannabinoids that stimulate in vitro hematopoietic stem cell migration effectively comparable to beta-adrenergic stimulation. Exp. Hematol. 2018, 57, 30-41.e1. [CrossRef]

31. Pereira, J.P.; An, J.; Xu, Y.; Huang, Y.; Cyster, J.G. Cannabinoid receptor 2 mediates the retention of immature B cells in bone marrow sinusoids. Nat. Immunol. 2009, 10, 403-411. [CrossRef] [PubMed]

32. Hoggatt, J.; Pelus, L.M. Eicosanoid regulation of hematopoiesis and hematopoietic stem and progenitor trafficking. Leukemia 2010, 24, 1993-2002. [CrossRef] [PubMed]

33. Khuja, I.; Yekhtin, Z.; Or, R.; Almogi-Hazan, O. Cannabinoids Reduce Inflammation but Inhibit Lymphocyte Recovery in Murine Models of Bone Marrow Transplantation. Int. J. Mol. Sci. 2019, 20, 668. [CrossRef] [PubMed]

34. Szabady, R.L.; Louissaint, C.; Lubben, A.; Xie, B.; Reeksting, S.; Tuohy, C.; Demma, Z.; Foley, S.E.; Faherty, C.S.; Llanos-Chea, A.; et al. Intestinal P-glycoprotein exports endocannabinoids to prevent inflammation and maintain homeostasis. J. Clin. Invest. 2018, 128, 4044-4056. [CrossRef]

35. Kapellos, T.S.; Taylor, L.; Feuerborn, A.; Valaris, S.; Hussain, M.T.; Rainger, G.E.; Greaves, D.R.; Iqbal, A.J. Cannabinoid receptor 2 deficiency exacerbates inflammation and neutrophil recruitment. Faseb. J. 2019, 33, 6154-6167. [CrossRef]

36. Tahamtan, A.; Samieipoor, Y.; Nayeri, F.S.; Rahbarimanesh, A.A.; Izadi, A.; Rashidi-Nezhad, A.; Tavakoli-Yaraki, M.; Farahmand, M.; Bont, L.; Shokri, F.; et al. Effects of cannabinoid receptor type 2 in respiratory syncytial virus infection in human subjects and mice. Virulence 2018, 9, 217-230. [CrossRef]

37. Lee, S.F.; Newton, C.; Widen, R.; Friedman, H.; Klein, T.W. Differential expression of cannabinoid CB(2) receptor mRNA in mouse immune cell subpopulations and following B cell stimulation. Eur. J. Pharm. 2001, 423, 235-241. [CrossRef]

38. Sugamura, K.; Sugiyama, S.; Nozaki, T.; Matsuzawa, Y.; Izumiya, Y.; Miyata, K.; Nakayama, M.; Kaikita, K.; Obata, T.; Takeya, M.; et al. Activated endocannabinoid system in coronary artery disease and antiinflammatory effects of cannabinoid 1 receptor blockade on macrophages. Circulation 2009, 119, 28-36. [CrossRef]

39. Chiurchiu, V.; Lanuti, M.; Catanzaro, G.; Fezza, F.; Rapino, C.; Maccarrone, M. Detailed characterization of the endocannabinoid system in human macrophages and foam cells, and anti-inflammatory role of type-2 cannabinoid receptor. Atherosclerosis 2014, 233, 55-63. [CrossRef]

40. Staiano, R.I.; Loffredo, S.; Borriello, F.; Iannotti, F.A.; Piscitelli, F.; Orlando, P.; Secondo, A.; Granata, F.; Lepore, M.T.; Fiorelli, A.; et al. Human lung-resident macrophages express CB1 and CB2 receptors whose activation inhibits the release of angiogenic and lymphangiogenic factors. J. Leukoc. Biol. 2016, 99, 531-540. [CrossRef]

41. Miranda, K.; Mehrpouya-Bahrami, P.; Nagarkatti, P.S.; Nagarkatti, M. Cannabinoid Receptor 1 Blockade Attenuates Obesity and Adipose Tissue Type 1 Inflammation Through miR-30e-5p Regulation of Delta-Like-4 in Macrophages and Consequently Downregulation of Th1 Cells. Front. Immunol. 2019, 10, 1049. [CrossRef] [PubMed]

42. Acharya, N.; Penukonda, S.; Shcheglova, T.; Hagymasi, A.T.; Basu, S.; Srivastava, P.K. Endocannabinoid system acts as a regulator of immune homeostasis in the gut. Proc. Natl. Acad. Sci. USA 2017, 114, 5005-5010. [CrossRef] [PubMed]

43. Xiang, W.; Shi, R.; Kang, X.; Zhang, X.; Chen, P.; Zhang, L.; Hou, A.; Wang, R.; Zhao, Y.; Zhao, K.; et al. Monoacylglycerol lipase regulates cannabinoid receptor 2-dependent macrophage activation and cancer progression. Nat. Commun. 2018, 9, 2574. [CrossRef] [PubMed]

44. Adhikary, S.; Kocieda, V.P.; Yen, J.H.; Tuma, R.F.; Ganea, D. Signaling through cannabinoid receptor 2 suppresses murine dendritic cell migration by inhibiting matrix metalloproteinase 9 expression. Blood 2012, 120, 3741-3749. [CrossRef] 
45. Maestroni, G.J. The endogenous cannabinoid 2-arachidonoyl glycerol as in vivo chemoattractant for dendritic cells and adjuvant for Th1 response to a soluble protein. Faseb. J. 2004, 18, 1914-1916. [CrossRef]

46. Gardner, B.; Zu, L.X.; Sharma, S.; Liu, Q.; Makriyannis, A.; Tashkin, D.P.; Dubinett, S.M. Autocrine and paracrine regulation of lymphocyte CB2 receptor expression by TGF-beta. Biochem. Biophys. Res. Commun. 2002, 290, 91-96. [CrossRef]

47. Robinson, R.H.; Meissler, J.J.; Breslow-Deckman, J.M.; Gaughan, J.; Adler, M.W.; Eisenstein, T.K. Cannabinoids inhibit T-cells via cannabinoid receptor 2 in an in vitro assay for graft rejection, the mixed lymphocyte reaction. J. Neuroimmune Pharm. 2013, 8, 1239-1250. [CrossRef]

48. Borner, C.; Hollt, V.; Kraus, J. Activation of human T cells induces upregulation of cannabinoid receptor type 1 transcription. Neuroimmunomodulation 2007, 14, 281-286.

49. Robinson, R.H.; Meissler, J.J.; Fan, X.; Yu, D.; Adler, M.W.; Eisenstein, T.K. A CB2-Selective Cannabinoid Suppresses T-Cell Activities and Increases Tregs and IL-10. J. Neuroimmune Pharm. 2015, 10, 318-332. [CrossRef]

50. Borner, C.; Smida, M.; Hollt, V.; Schraven, B.; Kraus, J. Cannabinoid receptor type 1- and 2-mediated increase in cyclic AMP inhibits T cell receptor-triggered signaling. J. Biol. Chem. 2009, 284, 35450-35460. [CrossRef]

51. Maresz, K.; Pryce, G.; Ponomarev, E.D.; Marsicano, G.; Croxford, J.L.; Shriver, L.P.; Ledent, C.; Cheng, X.; Carrier, E.J.; Mann, M.K.; et al. Direct suppression of CNS autoimmune inflammation via the cannabinoid receptor CB1 on neurons and CB2 on autoreactive T cells. Nat. Med. 2007, 13, 492-497. [CrossRef] [PubMed]

52. Sumida, H.; Lu, E.; Chen, H.; Yang, Q.; Mackie, K.; Cyster, J.G. GPR55 regulates intraepithelial lymphocyte migration dynamics and susceptibility to intestinal damage. Sci. Immunol. 2017, 2. [CrossRef] [PubMed]

53. Eisenstein, T.K.; Meissler, J.J.; Wilson, Q.; Gaughan, J.P.; Adler, M.W. Anandamide and Delta9tetrahydrocannabinol directly inhibit cells of the immune system via CB2 receptors. J. Neuroimmunol. 2007, 189, 17-22. [CrossRef] [PubMed]

54. Sido, J.M.; Nagarkatti, P.S.; Nagarkatti, M. Production of endocannabinoids by activated T cells and B cells modulates inflammation associated with delayed-type hypersensitivity. Eur. J. Immunol. 2016, 46, 1472-1479. [CrossRef]

55. Dotsey, E.; Ushach, I.; Pone, E.; Nakajima, R.; Jasinskas, A.; Argueta, D.A.; Dillon, A.; DiPatrizio, N.; Davies, H.; Zlotnik, A.; et al. Transient Cannabinoid Receptor 2 Blockade during Immunization Heightens Intensity and Breadth of Antigen-specific Antibody Responses in Young and Aged mice. Sci. Rep. 2017, 7, 42584. [CrossRef]

56. Medzhitov, R. Inflammation 2010: New adventures of an old flame. Cell 2010, 140, 771-776. [CrossRef]

57. Klein, T.W. Cannabinoid-based drugs as anti-inflammatory therapeutics. Nat. Rev. Immunol. 2005, 5, 400-411. [CrossRef]

58. Zgair, A.; Lee, J.B.; Wong, J.C.M.; Taha, D.A.; Aram, J.; Di Virgilio, D.; McArthur, J.W.; Cheng, Y.K.; Hennig, I.M.; Barrett, D.A.; et al. Oral administration of Cannabis with lipids leads to high levels of cannabinoids in the intestinal lymphatic system and prominent immunomodulation. Sci. Rep. 2017, 7, 14542. [CrossRef]

59. Bradley, S.G.; Munson, A.E.; Dewey, W.L.; Harris, L.S. Enhanced susceptibility of mice to combinations of delta 9-tetrahydrocannabinol and live or killed gram-negative bacteria. Infect. Immun. 1977, 17, 325-329. [CrossRef]

60. Morahan, P.S.; Klykken, P.C.; Smith, S.H.; Harris, L.S.; Munson, A.E. Effects of cannabinoids on host resistance to Listeria monocytogenes and herpes simplex virus. Infect. Immun. 1979, 23, 670-674. [CrossRef]

61. Cabral, G.A.; Rogers, T.J.; Lichtman, A.H. Turning Over a New Leaf: Cannabinoid and Endocannabinoid Modulation of Immune Function. J. Neuroimmune Pharm. 2015, 10, 193-203. [CrossRef] [PubMed]

62. Cabral, G.A.; Dove Pettit, D.A. Drugs and immunity: Cannabinoids and their role in decreased resistance to infectious disease. J. Neuroimmunol. 1998, 83, 116-123. [CrossRef]

63. Klein, T.W.; Friedman, H.; Specter, S. Marijuana, immunity and infection. J. Neuroimmunol. 1998, 83, $102-115$. [CrossRef]

64. Gu, Z.; Singh, S.; Niyogi, R.G.; Lamont, G.J.; Wang, H.; Lamont, R.J.; Scott, D.A. Marijuana-Derived Cannabinoids Trigger a CB2/PI3K Axis of Suppression of the Innate Response to Oral Pathogens. Front. Immunol. 2019, 10, 2288. [CrossRef] [PubMed] 
65. Hernandez-Cervantes, R.; Mendez-Diaz, M.; Prospero-Garcia, O.; Morales-Montor, J. Immunoregulatory Role of Cannabinoids during Infectious Disease. Neuroimmunomodulation 2017, 24, 183-199. [CrossRef] [PubMed]

66. Coppola, N.; Zampino, R.; Sagnelli, C.; Bellini, G.; Marrone, A.; Stanzione, M.; Capoluongo, N.; Boemio, A.; Minichini, C.; Adinolfi, L.E.; et al. Cannabinoid receptor 2-63 QQ variant is associated with persistently normal aminotransferase serum levels in chronic hepatitis C. PloS ONE 2014, 9, e99450. [CrossRef] [PubMed]

67. Sagnelli, C.; Uberti-Foppa, C.; Hasson, H.; Bellini, G.; Minichini, C.; Salpietro, S.; Messina, E.; Barbanotti, D.; Merli, M.; Punzo, F.; et al. In vivo evidence that the cannabinoid receptor 2-63 RR variant is associated with the acquisition and/or expansion of HIV infection. HIV Med. 2018, 19, 597-604. [CrossRef]

68. Appendino, G.; Gibbons, S.; Giana, A.; Pagani, A.; Grassi, G.; Stavri, M.; Smith, E.; Rahman, M.M. Antibacterial cannabinoids from Cannabis sativa: A structure-activity study. J. Nat. Prod. 2008, 71, 1427-1430. [CrossRef] [PubMed]

69. Tahamtan, A.; Tavakoli-Yaraki, M.; Rygiel, T.P.; Mokhtari-Azad, T.; Salimi, V. Effects of cannabinoids and their receptors on viral infections. J. Med. Virol. 2016, 88, 1-12. [CrossRef]

70. Blevins, R.D.; Dumic, M.P. The effect of delta-9-tetrahydrocannabinol on herpes simplex virus replication. J. Gen. Virol. 1980, 49, 427-431. [CrossRef]

71. Medveczky, M.M.; Sherwood, T.A.; Klein, T.W.; Friedman, H.; Medveczky, P.G. Delta-9 tetrahydrocannabinol (THC) inhibits lytic replication of gamma oncogenic herpesviruses in vitro. BMC Med. 2004, 2, 34. [CrossRef] [PubMed]

72. Akinola, O.; Ogbeche, E.O.; Olumoh-Abdul, H.A.; Alli-Oluwafuyi, A.O.; Oyewole, A.L.; Amin, A.; AbdulMajeed, W.I.; Olajide, O.J.; Nafiu, A.B.; Njan, A.A.; et al. Oral Ingestion of Cannabis sativa: Risks, Benefits, and Effects on Malaria-Infected Hosts. Cannabis Cannabinoid Res. 2018, 3, 219-227. [CrossRef] [PubMed]

73. Batugedara, H.M.; Argueta, D.; Jang, J.C.; Lu, D.; Macchietto, M.; Kaur, J.; Ge, S.; Dillman, A.R.; DiPatrizio, N.V.; Nair, M.G. Host- and Helminth-Derived Endocannabinoids That Have Effects on Host Immunity Are Generated during Infection. Infect. Immun. 2018, 86, 11. [CrossRef] [PubMed]

74. Kiertscher, S.M.; Gangalum, P.R.; Ibrahim, G.; Tashkin, D.P.; Roth, M.D. A Prospective Study of Humoral and Cellular Immune Responses to Hepatitis B Vaccination in Habitual Marijuana Smokers. J. Neuroimmune Pharm. 2018, 13, 219-229. [CrossRef]

75. Brown, D.; Watson, M.; Schloss, J. Pharmacological evidence of medicinal Cannabis in oncology: A systematic review. Support Care Cancer 2019, 27, 3195-3207. [CrossRef] [PubMed]

76. Velasco, G.; Sanchez, C.; Guzman, M. Towards the use of cannabinoids as antitumour agents. Nat. Rev. Cancer 2012, 12, 436-444. [CrossRef] [PubMed]

77. Baram, L.; Peled, E.; Berman, P.; Yellin, B.; Besser, E.; Benami, M.; Louria-Hayon, I.; Lewitus, G.M.; Meiri, D. The heterogeneity and complexity of Cannabis extracts as antitumor agents. Oncotarget 2019, 10, 4091-4106. [CrossRef]

78. Qiu, C.; Yang, L.; Wang, B.; Cui, L.; Li, C.; Zhuo, Y.; Zhang, L.; Zhang, S.; Zhang, Q.; Wang, X. The role of 2-arachidonoylglycerol in the regulation of the tumor-immune microenvironment in murine models of pancreatic cancer. Biomed Pharm. 2019, 115, 108952. [CrossRef]

79. Blasco-Benito, S.; Moreno, E.; Seijo-Vila, M.; Tundidor, I.; Andradas, C.; Caffarel, M.M.; Caro-Villalobos, M.; Uriguen, L.; Diez-Alarcia, R.; Moreno-Bueno, G.; et al. Therapeutic targeting of HER2-CB2R heteromers in HER2-positive breast cancer. Proc. Natl. Acad. Sci. USA 2019, 116, 3863-3872. [CrossRef]

80. Ladin, D.A.; Soliman, E.; Griffin, L.; Van Dross, R. Preclinical and Clinical Assessment of Cannabinoids as Anti-Cancer Agents. Front. Pharm. 2016, 7, 361. [CrossRef]

81. Moreno, E.; Cavic, M.; Krivokuca, A.; Casado, V.; Canela, E. The Endocannabinoid System as a Target in Cancer Diseases: Are We There Yet? Front. Pharm. 2019, 10, 339. [CrossRef] [PubMed]

82. Fraguas-Sanchez, A.I.; Martin-Sabroso, C.; Torres-Suarez, A.I. Insights into the effects of the endocannabinoid system in cancer: A review. Br. J. Pharm. 2018, 175, 2566-2580. [CrossRef] [PubMed]

83. Dunn, G.P.; Old, L.J.; Schreiber, R.D. The immunobiology of cancer immunosurveillance and immunoediting. Immunity 2004, 21, 137-148. [CrossRef] [PubMed]

84. Sanmamed, M.F.; Chen, L. A Paradigm Shift in Cancer Immunotherapy: From Enhancement to Normalization. Cell 2018, 175, 313-326. [CrossRef] 
85. McKallip, R.J.; Nagarkatti, M.; Nagarkatti, P.S. Delta-9-tetrahydrocannabinol enhances breast cancer growth and metastasis by suppression of the antitumor immune response. J. Immunol. 2005, 174, 3281-3289. [CrossRef]

86. Zhu, L.X.; Sharma, S.; Stolina, M.; Gardner, B.; Roth, M.D.; Tashkin, D.P.; Dubinett, S.M. Delta-9tetrahydrocannabinol inhibits antitumor immunity by a CB2 receptor-mediated, cytokine-dependent pathway. J. Immunol. 2000, 165, 373-380. [CrossRef] [PubMed]

87. Blazquez, C.; Carracedo, A.; Barrado, L.; Real, P.J.; Fernandez-Luna, J.L.; Velasco, G.; Malumbres, M.; Guzman, M. Cannabinoid receptors as novel targets for the treatment of melanoma. FASEB J. 2006, 20, 2633-2635. [CrossRef]

88. Taha, T.; Meiri, D.; Talhamy, S.; Wollner, M.; Peer, A.; Bar-Sela, G. Cannabis Impacts Tumor Response Rate to Nivolumab in Patients with Advanced Malignancies. Oncologist 2019, 24, 549-554. [CrossRef]

89. Katz, D.; Katz, I.; Porat-Katz, B.S.; Shoenfeld, Y. Medical Cannabis: Another piece in the mosaic of autoimmunity? Clin. Pharm. 2017, 101, 230-238. [CrossRef]

90. Kozela, E.; Juknat, A.; Kaushansky, N.; Rimmerman, N.; Ben-Nun, A.; Vogel, Z. Cannabinoids decrease the th17 inflammatory autoimmune phenotype. J. Neuroimmune Pharm. 2013, 8, 1265-1276. [CrossRef]

91. Gentili, M.; Ronchetti, S.; Ricci, E.; Di Paola, R.; Gugliandolo, E.; Cuzzocrea, S.; Bereshchenko, O.; Migliorati, G.; Riccardi, C. Selective CB2 inverse agonist JTE907 drives T cell differentiation towards a Treg cell phenotype and ameliorates inflammation in a mouse model of inflammatory bowel disease. Pharm. Res. 2019, 141, 21-31. [CrossRef] [PubMed]

92. Malfait, A.M.; Gallily, R.; Sumariwalla, P.F.; Malik, A.S.; Andreakos, E.; Mechoulam, R.; Feldmann, M. The nonpsychoactive Cannabis constituent cannabidiol is an oral anti-arthritic therapeutic in murine collagen-induced arthritis. Proc. Natl. Acad. Sci. USA 2000, 97, 9561-9566. [CrossRef] [PubMed]

93. Gui, H.; Liu, X.; Liu, L.R.; Su, D.F.; Dai, S.M. Activation of cannabinoid receptor 2 attenuates synovitis and joint distruction in collagen-induced arthritis. Immunobiology 2015, 220, 817-822. [CrossRef]

94. Lowin, T.; Apitz, M.; Anders, S.; Straub, R.H. Anti-inflammatory effects of N-acylethanolamines in rheumatoid arthritis synovial cells are mediated by TRPV1 and TRPA1 in a COX-2 dependent manner. Arthritis Res. 2015, 17, 321. [CrossRef] [PubMed]

95. McDougall, J.J.; Muley, M.M.; Philpott, H.T.; Reid, A.; Krustev, E. Early blockade of joint inflammation with a fatty acid amide hydrolase inhibitor decreases end-stage osteoarthritis pain and peripheral neuropathy in mice. Arthritis Res. 2017, 19, 1-9. [CrossRef]

96. Richardson, D.; Pearson, R.G.; Kurian, N.; Latif, M.L.; Garle, M.J.; Barrett, D.A.; Kendall, D.A.; Scammell, B.E.; Reeve, A.J.; Chapman, V. Characterisation of the cannabinoid receptor system in synovial tissue and fluid in patients with osteoarthritis and rheumatoid arthritis. Arthritis Res. 2008, 10, R43. [CrossRef]

97. Tripathi, R.K.P. A perspective review on fatty acid amide hydrolase (FAAH) inhibitors as potential therapeutic agents. Eur. J. Med. Chem. 2020, 188, 111953. [CrossRef]

98. Kerbrat, A.; Ferré, J.C.; Fillatre, P.; Ronzière, T.; Vannier, S.; Carsin-Nicol, B.; Lavoué, S.; Vérin, M.; Gauvrit, J.Y.; Le Tulzo, Y.; et al. Acute Neurologic Disorder from an Inhibitor of Fatty Acid Amide Hydrolase. N. Engl. J. Med. 2016, 375, 1717-1725. [CrossRef]

99. Blake, D.R.; Robson, P.; Ho, M.; Jubb, R.W.; McCabe, C.S. Preliminary assessment of the efficacy, tolerability and safety of a Cannabis-based medicine (Sativex) in the treatment of pain caused by rheumatoid arthritis. Rheumatology 2006, 45, 50-52. [CrossRef]

100. Lyman, W.D.; Sonett, J.R.; Brosnan, C.F.; Elkin, R.; Bornstein, M.B. Delta 9-tetrahydrocannabinol: A novel treatment for experimental autoimmune encephalomyelitis. J. Neuroimmunol. 1989, 23, 73-81. [CrossRef]

101. Pryce, G.; Riddall, D.R.; Selwood, D.L.; Giovannoni, G.; Baker, D. Neuroprotection in Experimental Autoimmune Encephalomyelitis and Progressive Multiple Sclerosis by Cannabis-Based Cannabinoids. J. Neuroimmune Pharm. 2015, 10, 281-292. [CrossRef] [PubMed]

102. Kozela, E.; Lev, N.; Kaushansky, N.; Eilam, R.; Rimmerman, N.; Levy, R.; Ben-Nun, A.; Juknat, A.; Vogel, Z. Cannabidiol inhibits pathogenic $\mathrm{T}$ cells, decreases spinal microglial activation and ameliorates multiple sclerosis-like disease in C57BL/6 mice. Br. J. Pharm. 2011, 163, 1507-1519. [CrossRef] [PubMed]

103. Sexton, M.; Cudaback, E.; Abdullah, R.A.; Finnell, J.; Mischley, L.K.; Rozga, M.; Lichtman, A.H.; Stella, N. Cannabis use by individuals with multiple sclerosis: Effects on specific immune parameters. Inflammopharmacology 2014, 22, 295-303. [CrossRef] [PubMed] 
104. da Rovare, V.P.; Magalhaes, G.P.A.; Jardini, G.D.A.; Beraldo, M.L.; Gameiro, M.O.; Agarwal, A.; Luvizutto, G.J.; Paula-Ramos, L.; Camargo, S.E.A.; de Oliveira, L.D.; et al. Cannabinoids for spasticity due to multiple sclerosis or paraplegia: A systematic review and meta-analysis of randomized clinical trials. Complement Med. 2017, 34, 170-185. [CrossRef] [PubMed]

105. Akgun, K.; Essner, U.; Seydel, C.; Ziemssen, T. Daily Practice Managing Resistant Multiple Sclerosis Spasticity With Delta-9-Tetrahydrocannabinol: Cannabidiol Oromucosal Spray: A Systematic Review of Observational Studies. J Cent Nerv. Syst. Dis. 2019, 11, 1179573519831997. [CrossRef]

106. Leinwand, K.L.; Gerich, M.E.; Hoffenberg, E.J.; Collins, C.B. Manipulation of the Endocannabinoid System in Colitis: A Comprehensive Review. Inflamm. Bowel Dis. 2017, 23, 192-199. [CrossRef]

107. Storr, M.A.; Keenan, C.M.; Emmerdinger, D.; Zhang, H.; Yüce, B.; Sibaev, A.; Massa, F.; Buckley, N.E.; Lutz, B.; Göke, B.; et al. Targeting endocannabinoid degradation protects against experimental colitis in mice: Involvement of CB1 and CB2 receptors. J. Mol. Med. 2008, 86, 925-936. [CrossRef]

108. Alhouayek, M.; Lambert, D.M.; Delzenne, N.M.; Cani, P.D.; Muccioli, G.G. Increasing endogenous 2-arachidonoylglycerol levels counteracts colitis and related systemic inflammation. FASEB J. 2011, 25, 2711-2721. [CrossRef]

109. Grill, M.; Högenauer, C.; Blesl, A.; Haybaeck, J.; Golob-Schwarzl, N.; Ferreirós, N.; Thomas, D.; Gurke, R.; Trötzmüller, M.; Köfeler, H.C.; et al. Members of the endocannabinoid system are distinctly regulated in inflammatory bowel disease and colorectal cancer. Sci. Rep. 2019, 9, 2358. [CrossRef]

110. Ambrose, T.; Simmons, A. Cannabis, Cannabinoids, and the Endocannabinoid System-Is there Therapeutic Potential for Inflammatory Bowel Disease? J. Crohns Colitis 2019, 13, 525-535. [CrossRef]

111. Naftali, T.; Bar-Lev Schleider, L.; Dotan, I.; Lansky, E.P.; Sklerovsky Benjaminov, F.; Konikoff, F.M. Cannabis induces a clinical response in patients with Crohn's disease: A prospective placebo-controlled study. Clin. Gastroenterol. Hepatol. 2013, 11, 1276-1280.e1. [CrossRef] [PubMed]

112. Irving, P.M.; Iqbal, T.; Nwokolo, C.; Subramanian, S.; Bloom, S.; Prasad, N.; Hart, A.; Murray, C.; Lindsay, J.O.; Taylor, A.; et al. Double-blind, Placebo-controlled, Parallel-group, Pilot Study of Cannabidiol-rich Botanical Extract in the Symptomatic Treatment of Ulcerative Colitis. Inflamm. Bowel Dis. 2018, 24, 714-724. [CrossRef] [PubMed]

113. Mbachi, C.; Attar, B.; Oyenubi, O.; Yuchen, W.; Efesomwan, A.; Paintsil, I.; Madhu, M.; Ajiboye, O.; Simons-Linares, C.R.; Trick, W.E.; et al. Association between Cannabis use and complications related to ulcerative colitis in hospitalized patients: A propensity matched retrospective cohort study. Medicine 2019, 98, e16551. [CrossRef] [PubMed]

114. Couch, D.G.; Cook, H.; Ortori, C.; Barrett, D.; Lund, J.N.; O'Sullivan, S.E. Palmitoylethanolamide and Cannabidiol Prevent Inflammation-induced Hyperpermeability of the Human Gut In Vitro and In Vivo-A Randomized, Placebo-Controlled, Double-Blind Controlled Trial. Inflamm. Bowel Dis. 2019, 25, 1006-1018. [CrossRef]

115. Hegde, V.L.; Hegde, S.; Cravatt, B.F.; Hofseth, L.J.; Nagarkatti, M.; Nagarkatti, P.S. Attenuation of experimental autoimmune hepatitis by exogenous and endogenous cannabinoids: Involvement of regulatory $\mathrm{T}$ cells. Mol. Pharm. 2008, 74, 20-33. [CrossRef]

116. Morsch, M.; Protti, D.A.; Cheng, D.; Braet, F.; Chung, R.S.; Reddel, S.W.; Phillips, W.D. Cannabinoid-induced increase of quantal size and enhanced neuromuscular transmission. Sci. Rep. 2018, 8, 4685. [CrossRef]

117. Xu, H.; Cheng, C.L.; Chen, M.; Manivannan, A.; Cabay, L.; Pertwee, R.G.; Coutts, A.; Forrester, J.V. Anti-inflammatory property of the cannabinoid receptor-2-selective agonist JWH-133 in a rodent model of autoimmune uveoretinitis. J. Leukoc. Biol. 2007, 82, 532-541. [CrossRef]

118. Katz-Talmor, D.; Kivity, S.; Blank, M.; Katz, I.; Perry, O.; Volkov, A.; Barshack, I.; Amital, H.; Shoenfeld, Y. Cannabidiol Treatment in a Murine Model of Systemic Lupus Erythematosus Accelerates Proteinuria Development. Isr. Med. Assoc. J. 2018, 20, 741.

119. Navarini, L.; Bisogno, T.; Mozetic, P.; Piscitelli, F.; Margiotta, D.P.E.; Basta, F.; Afeltra, A.; Maccarrone, M. Endocannabinoid system in systemic lupus erythematosus: First evidence for a deranged 2-arachidonoylglycerol metabolism. Int. J. Biochem. Cell Biol. 2018, 99, 161-168. [CrossRef]

120. Rahaman, O.; Bhattacharya, R.; Liu, C.S.C.; Raychaudhuri, D.; Ghosh, A.R.; Bandopadhyay, P.; Pal, S.; Goswami, R.P.; Sircar, G.; Ghosh, P.; et al. Cutting Edge: Dysregulated Endocannabinoid-Rheostat for Plasmacytoid Dendritic Cell Activation in a Systemic Lupus Endophenotype. J. Immunol. 2019, 202, 1674-1679. [CrossRef] 
121. Imtiaz, S.; Rehm, J. The relationship between Cannabis use and diabetes: Results from the National Epidemiologic Survey on Alcohol and Related Conditions III. Drug Alcohol Rev. 2018, 37, 897-902. [CrossRef] [PubMed]

122. Danielsson, A.K.; Lundin, A.; Yaregal, A.; Ostenson, C.G.; Allebeck, P.; Agardh, E.E. Cannabis Use as Risk or Protection for Type 2 Diabetes: A Longitudinal Study of 18000 Swedish Men and Women. J. Diabetes Res. 2016, 2016. [CrossRef] [PubMed]

123. Nagarkatti, M.; Rieder, S.A.; Hegde, V.L.; Kanada, S.; Nagarkatti, P. Do cannabinoids have a therapeutic role in transplantation? Trends Pharm. Sci. 2010, 31, 345-350. [CrossRef] [PubMed]

124. Rai, H.S.; Winder, G.S. Marijuana Use and Organ Transplantation: A Review and Implications for Clinical Practice. Curr. Psychiatry Rep. 2017, 19, 91. [CrossRef]

125. Pandey, R.; Hegde, V.L.; Nagarkatti, M.; Nagarkatti, P.S. Targeting cannabinoid receptors as a novel approach in the treatment of graft-versus-host disease: Evidence from an experimental murine model. J. Pharm. Exp. 2011, 338, 819-828. [CrossRef] [PubMed]

126. Sido, J.M.; Nagarkatti, P.S.; Nagarkatti, M. Delta(9)-Tetrahydrocannabinol attenuates allogeneic host-versus-graft response and delays skin graft rejection through activation of cannabinoid receptor 1 and induction of myeloid-derived suppressor cells. J. Leukoc. Biol. 2015, 98, 435-447. [CrossRef] [PubMed]

127. Yeshurun, M.; Shpilberg, O.; Herscovici, C.; Shargian, L.; Dreyer, J.; Peck, A.; Israeli, M.; Levy-Assaraf, M.; Gruenewald, T.; Mechoulam, R.; et al. Cannabidiol for the Prevention of Graft-versus-Host-Disease after Allogeneic Hematopoietic Cell Transplantation: Results of a Phase II Study. Biol. Blood Marrow Transpl. 2015, 21, 1770-1775. [CrossRef]

128. Cunetti, L.; Manzo, L.; Peyraube, R.; Arnaiz, J.; Curi, L.; Orihuela, S. Chronic Pain Treatment With Cannabidiol in Kidney Transplant Patients in Uruguay. Transpl. Proc. 2018, 50, 461-464. [CrossRef]

129. Greenan, G.; Ahmad, S.B.; Anders, M.G.; Leeser, A.; Bromberg, J.S.; Niederhaus, S.V. Recreational marijuana use is not associated with worse outcomes after renal transplantation. Clin. Transpl. 2016, 30, 1340-1346. [CrossRef]

130. Pagano, E.; Capasso, R.; Piscitelli, F.; Romano, B.; Parisi, O.A.; Finizio, S.; Lauritano, A.; Marzo, V.D.; Izzo, A.A.; Borrelli, F. An Orally Active Cannabis Extract with High Content in Cannabidiol attenuates Chemically-induced Intestinal Inflammation and Hypermotility in the Mouse. Front. Pharm. 2016, 7, 341. [CrossRef]

131. Brierley, D.I.; Samuels, J.; Duncan, M.; Whalley, B.J.; Williams, C.M. A cannabigerol-rich Cannabis sativa extract, devoid of [INCREMENT]9-tetrahydrocannabinol, elicits hyperphagia in rats. Behav. Pharm. 2017, 28, 280-284. [CrossRef] [PubMed]

132. Russo, E.B. Taming THC: Potential Cannabis synergy and phytocannabinoid-terpenoid entourage effects. Br. J. Pharm. 2011, 163, 1344-1364. [CrossRef] [PubMed]

133. Kamal, B.S.; Kamal, F.; Lantela, D.E. Cannabis and the Anxiety of Fragmentation-A Systems Approach for Finding an Anxiolytic Cannabis Chemotype. Front Neurosci. 2018, 12, 730. [CrossRef] [PubMed]

134. Johnson, J.R.; Burnell-Nugent, M.; Lossignol, D.; Ganae-Motan, E.D.; Potts, R.; Fallon, M.T. Multicenter, double-blind, randomized, placebo-controlled, parallel-group study of the efficacy, safety, and tolerability of THC:CBD extract and THC extract in patients with intractable cancer-related pain. J. Pain Symptom Manag. 2010, 39, 167-179. [CrossRef] [PubMed]

135. Morgan, C.J.A.; Freeman, T.P.; Hindocha, C.; Schafer, G.; Gardner, C.; Curran, H.V. Individual and combined effects of acute delta-9-tetrahydrocannabinol and cannabidiol on psychotomimetic symptoms and memory function. Transl. Psychiatry 2018, 8, 181. [CrossRef] [PubMed]

136. Chatkin, J.M.; Zani-Silva, L.; Ferreira, I.; Zamel, N. Cannabis-Associated Asthma and Allergies. Clin. Rev. Allergy Immunol. 2019, 56, 196-206. [CrossRef]

137. Decuyper, II; Van Gasse, A.L.; Cop, N.; Sabato, V.; Faber, M.A.; Mertens, C.; Bridts, C.H.; Hagendorens, M.M.; De Clerck, L.; Rihs, H.P.; et al. Cannabis sativa allergy: Looking through the fog. Allergy 2017, 72, 201-206. [CrossRef]

138. Silvers, W.S.; Bernard, T. Spectrum and prevalence of reactions to marijuana in a Colorado allergy practice. Ann. Allergy Asthma Immunol. 2017, 119, 570-571. [CrossRef]

139. Ebo, D.G.; Swerts, S.; Sabato, V.; Hagendorens, M.M.; Bridts, C.H.; Jorens, P.G.; De Clerck, L.S. New food allergies in a European non-Mediterranean region: Is Cannabis sativa to blame? Int. Arch. Allergy Immunol. 2013, 161, 220-228. [CrossRef]

(C) 2020 by the authors. Licensee MDPI, Basel, Switzerland. This article is an open access article distributed under the terms and conditions of the Creative Commons Attribution (CC BY) license (http://creativecommons.org/licenses/by/4.0/). 